\title{
Subulura mackoi n. sp. (Nematoda: Subuluridae) and the zoogeography of subulurids parasitizing birds
}

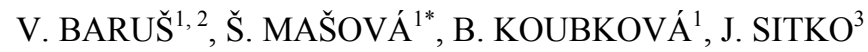 \\ ${ }^{1}$ Department of Botany and Zoology Faculty of Science, Masaryk University, Kotlářská 2, 61137 Brno, Czech \\ Republic, *E-mail: masova@sci.muni.cz; ${ }^{2}$ Institute of Vertebrate Biology, Academy of Sciences of the Czech \\ Republic, Květná 8, 60365 Brno, Czech Republic; ${ }^{3}$ Comenius Museum, Moravian Ornithological Station, \\ Horní nám. 7, 75102 Přerov, Czech Republic
}

\begin{abstract}
Summary
A new nematode species, Subulura mackoi n. sp., is described based on specimens from the colon and caecum of the Eurasian Scops Owl Otus scops (L.) (Aves: Strigiformes) from the Czech Republic, collected in 2011. Males are characterized by 10 pairs of caudal papillae, a single papilla on the upper lip of the cloaca, and small unequal spiculae; female distinguishing features are body length, distance of the vulva from the anterior extremity, tail length, and egg dimension.

Analysis of the zoogeographical distribution and host specialization (in the bird orders) of 68 valid species from the genus Subulura Molin, 1860 shows significantly high species diversity in the tropical zones. Only one species, $S$. brumpti, is a cosmopolitan parasite of Gallus gallus $\mathrm{f}$. domestica and other domesticated gallinaceous birds. Zoogeographical-host interactions may be utilized to support the identification of morphospecies of the genus Subulura.
\end{abstract}

Keywords: Subulura; new species; Otus scops; Aves; distribution

\section{Introduction}

So far, twelve species of owls have been confirmed in the avifauna of the Czech Republic; the rarest and most interesting of them is the Eurasian Scops Owl Otus scops (L.). The Czech and Slovak Republics are their northernmost nesting area in Central Europe. The Eurasian Scops Owl returns there from its wintering grounds in the sub-Saharan region between the end of April and the beginning of May (Hudec \& Št’astný, 2005). Nematodes determined as Subulura spp. in O. scops were found only by Ferrer et al. (2004) in Spain. The morphometric study of specimens in our collection and comparison with all bird species of Subulura Molin, 1860 revealed that it represents a new species, which is described herein. The geographical distributions of all valid species parasitizing birds were analyzed.

\section{Material and methods}

One already dead specimen of Eurasian Scops Owl (roadkill - 28.4.2011, Přerov, Czech Republic) was helminthologically examined. In total, eight Subulura nematodes (5 males and 3 females) were obtained from the colon and caecum. The nematodes were washed in physiological saline, then fixed and stored in $4 \%$ formaldehyde solution. For light microscopy three males and two females were cleared with glycerine. Specimens were examined under an Olympus BX51 light microscope equipped with Nomarski (DIC) optics differential interference contrast, a digital image analysis system (Motion Stream, Olympus), and a drawing tube attachment. Measurements are in micrometers $(\mu \mathrm{m})$, unless otherwise stated. Two males and one female were used for scanning electron microscopy (SEM). They were prepared by standard methods described by Mašová (2012) and examined using a Quanta TM 250 FEG scanning electron microscope at an accelerating voltage of $10 \mathrm{kV}$. The names of strigiform birds follow Del Hoyo et al. (1999). The names of biogeogrephical realms follow Olson et al. (2004).

\section{Results}

Subuluridae Yorke et Maplestone, 1926

Subulura mackoi $\mathrm{n} . \mathrm{sp}$.

(Figs. 1 - 19)

Description: Whitish nematodes tapering to both extremities, anterior part with obtuse cephalic end. Cephalic plate with smooth cuticle, mouth opening terminal, hexagonal and dorsoventrally protracted (Figs. 1, 10), surrounded by six reduced labial lobes, each with two tiny cuticular lappets without papillae (Fig. 11). Four large cephalic papillae present on lateral margin of cephalic plate arranged in two groups; prominent amphid opening located between papillae. Buccal capsule sclerotized and thickly walled, round in 

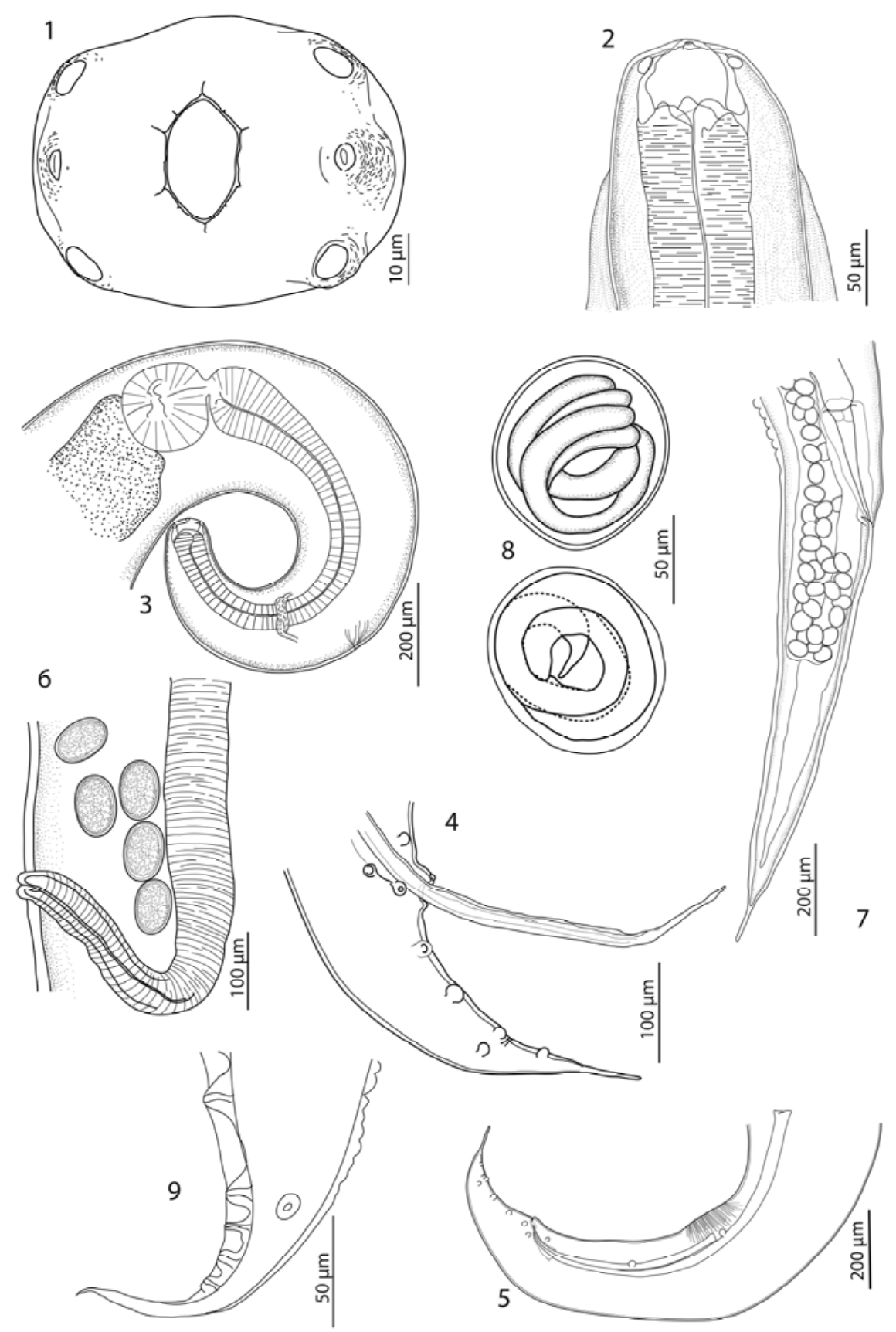

Figs. 1 - 8. Subulura mackoi n.sp.; line drawings. Fig. 1. Female cephalic end (apical view); Fig. 2. Female anterior end (dorsal view); Fig. 3. Male anterior part (lateral view); Fig. 4. Paracloacal and postcloacal papillae on male posterior end (lateral view); Fig. 5. Male posterior end with precloacal sucker (lateral view); Fig. 6. Vulval region (lateral view); Fig. 7. Female posterior end (lateral view); Fig. 8. Eggs; Fig. 9. Subulura glaucidii (López-Neyra, 1945); distribution of lower group of postcloacal caudal papillae (according to López-Neyra 1945).

cross section, anterior rim smooth (Figs. 2, 11). Anterior end of pharynx prolonged into three sclerotized teeth (Fig. 2); oesophagus dilated posteriorly with short neck followed by bulb containing dental apparatus (Fig. 3). Two lateral cervical alae, 50 - 63 in maximum width, beginning at level of anterior end of short pharynx (Fig. 12), ending slightly anterior to oesophageal bulb. Deirids not observed. Body cuticle with numerous and varied transverse striations, including slender tail point (Fig. 18).
Male (3 specimens; holotype and measurements of 2 paratypes in parentheses): Body $10.77(10.71-11.69) \mathrm{mm}$ long, $360(329-342)$ greatest width near middle of body. Buccal capsule $23(21-26)$ long, $47(43-54)$ wide, teeth in oesophageal funnel 9 (10) long. Total oesophagus 923 (1083 - 1198) long, oesophageal bulb $179(144-172)$ wide. Nerve ring $290(289-311)$ and excretory pore 570 (468 - 530) from anterior end, respectively. Tail (cloaca to tail tip) $264(259-260)$ long, prolonged into slender point 
48 (58 - 60) long. Praecloacal muscular sucker elliptical without cuticular ring $224(197$ - 201) long, its bottom margin 370 (356 - 375) from cloaca (Figs. 5, 14). Total of ten pairs of caudal papillae present, three being precloacal, two paracloacal, and five postcloacal. One median single papilla located on the upper lip of cloaca (Fig. 13). Papillae in pairs arranged as follows: first pair lateral and approximately in half of length of preanal sucker; second pair approximately half way between bottom margin of preanal sucker and cloaca; third pair between previous pair of papillae and cloaca; fourth and fifth pair juxtaposed paracloacally; sixth to eighth pair equally distributed in one line ventrally, ninth pair of papillae located laterally at the level of the eighth pair of postcloacal papillae; tenth pair again lies ventrally (Figs. 4, 14, 15). Spiculae unequal, right spicule 621 (539 - 582) long, left spicule 815 (807855) long, both spicules bialate (Fig. 16). Alae end approximately $84(82) \mu \mathrm{m}$ from the acerate top of spicule (Fig. 17). Gubernaculum 106 (99 - 123) long, Y-shaped.

Female (2 specimens; allotype and measurements of 1 paratype in parentheses): Body 16.90 (11.90) mm long, 460 (376) maximum width in middle of body, body width at level of anus 176 (171). Buccal capsule 31 (28) long, 51(45) wide, teeth in oesophageal funnel 16 (15) long. Total oesophagus 1787 (1234) long. Posterior oesophageal bulb 178 (202) wide. Nerve ring 283 (246) and excretory pore 443 (399) from anterior end, respectively. Vulva preequatorial, 6.43 (5.50) $\mathrm{mm}$ from anterior end of body, form of transverse slit with slightly elevated margins (Fig. 6). Tail 870 (832) long, prolonged into slender point 76 (72) long (Figs. 7, 19). Eggs ( $\mathrm{n}=15$ for both specimens) ovoid with smooth shell, 46 - 52 (mean 49.6) long, $39-48$ (mean 42.3) wide, with well-developed larvae (Fig. 8).

Taxonomic summary

Type specimens: Holotype - male; Allotype - female; two male and one female paratypes (cat. N-995) deposited in the Helminthological collection of the Institute of Parasitology, the Biology Centre, ASCR, v.v.i., Branišovská 31, 37005 České Budějovice, Czech Republic.

Type host: Otus scops (Linnaeus, 1758), Strigidae (Otini) Eurasian Scops Owl.

Site of infection: colon and caecum.

Type locality: Přerov, 6570 (number of map field according to the European mapping network), Czech Republic, Europe.

Intensity of infection: Eight nematode specimens ( 5 males and 3 females) in a single host.

Etymology: Specific epithet in honour of our colleague Josef K. Macko, Institute of Parasitology, the Slovak Academy of Sciences, Košice, Slovak Republic, a worldrenowned specialist in morphology, systematics, the species diversity of helminth parasites of birds, and general helminthology.

Remarks

The new species is placed in Subulura Molin, 1960 (Ne- matoda: Subuluridae) because its morphology fully corresponds with the generic diagnoses by Yamaguti (1961), Skryabin et al. (1964) and Vincente et al. (1995). Sixtyseven valid species of the genus Subulura parasitizing birds are widely recognized (see zoogeographical analysis). Out of these species, 10 species are specialized parasites of birds of the order Strigiformes. They are divided into two morphological groups. The first group with six species contains males with equal spicules and 10 or 11 pairs of caudal papillae: Subulura alfenensis Pinto, 1968 host Athene cunicularia (Molina), Brasil; S. chinensis Schwartz, 1926 - Otus stictonotus (Sharpe), China; S. noctuae (Seurat, 1914) - Athene noctua glaux (Savigny), Africa, Algeria; S. bolivari (López-Neyra, 1922) - Athene noctua (Scopoli), Europe, Spain all have ten pairs of caudal papillae; and S. albai Argawal, 1965 - Tyto alba (Scopoli), India, Lucknow and S. similis (Gendre, 1909) - from three bird orders (Coraciiformes, Cuculiformes and Strigiformes), Africa all have 11 pairs of caudal papillae. We consider the last mentioned species as species inquirenda by virtue of its incomplete description and the existence of host differences. Cram (1927) in her determination key [and also López-Neyra (1945)] placed the species $S$. similis in the group of subulurids with equal spicules and described a group of the lower caudal papillae as follows: "the most posterior pairs of caudal papillae are dissimilar, the second being shorter and more slender, the third ventral pair is at least as large as the first pair and is in close juxtaposition with the second pair." Subulura mackoi n. sp. differs from $S$. similis in the number and distribution of caudal papillae and unequal spiculae. According to Gendre (1909), in S. similis from the host Ptilopsis leucotis (Temminck), the body length of males is $12.6-15.0 \mathrm{~mm}$, and that of females is $20.12-22.45 \mathrm{~mm}$. The ratio of vulva distance from anterior body end for samples of all three different hosts is 1:2.3. The vulva of females from $P$. leucotis is a shorter distance $(6.09-6.80 \mathrm{~mm})$ from the anterior body end than the vulva in $S$. mackoi n. sp., i. e. in ratio of vulva distance from anterior body end to total body length $30.2-30.3 \%$, only. Another two species of subulurids, described from other host orders which were later found in Strigiformes, are known besides the above mentioned parasites from this morphological group. The first is S. forcipata (Rudolphi, 1819) - an obligatory parasite of Cuculiformes in South America (Vicente et al., 1995) reported by Kinsella et al. (2001) in Athene cunicularia in USA (Florida). Males of this species have 10 pairs of caudal papillae and an equal spiculae length of 677 (Barreto, 1919); the second is $S$. galloperdicis Baylis et Daubney, 1922 - a common parasite of Galliformes reported once by Sood (2006) in Tyto alba in India. Males have 11 pairs of caudal papillae and an equal spiculae length of $760-800$ (Baylis, 1936). Both taxa are clearly different from $S$. mackoi n. sp. in virtue of these and other species value characters.

The newly described $S$. mackoi $\mathrm{n}$. sp. belongs to the second group of four specialized parasites of Strigiformes, in which males are characterized by unequal spiculae and 10 

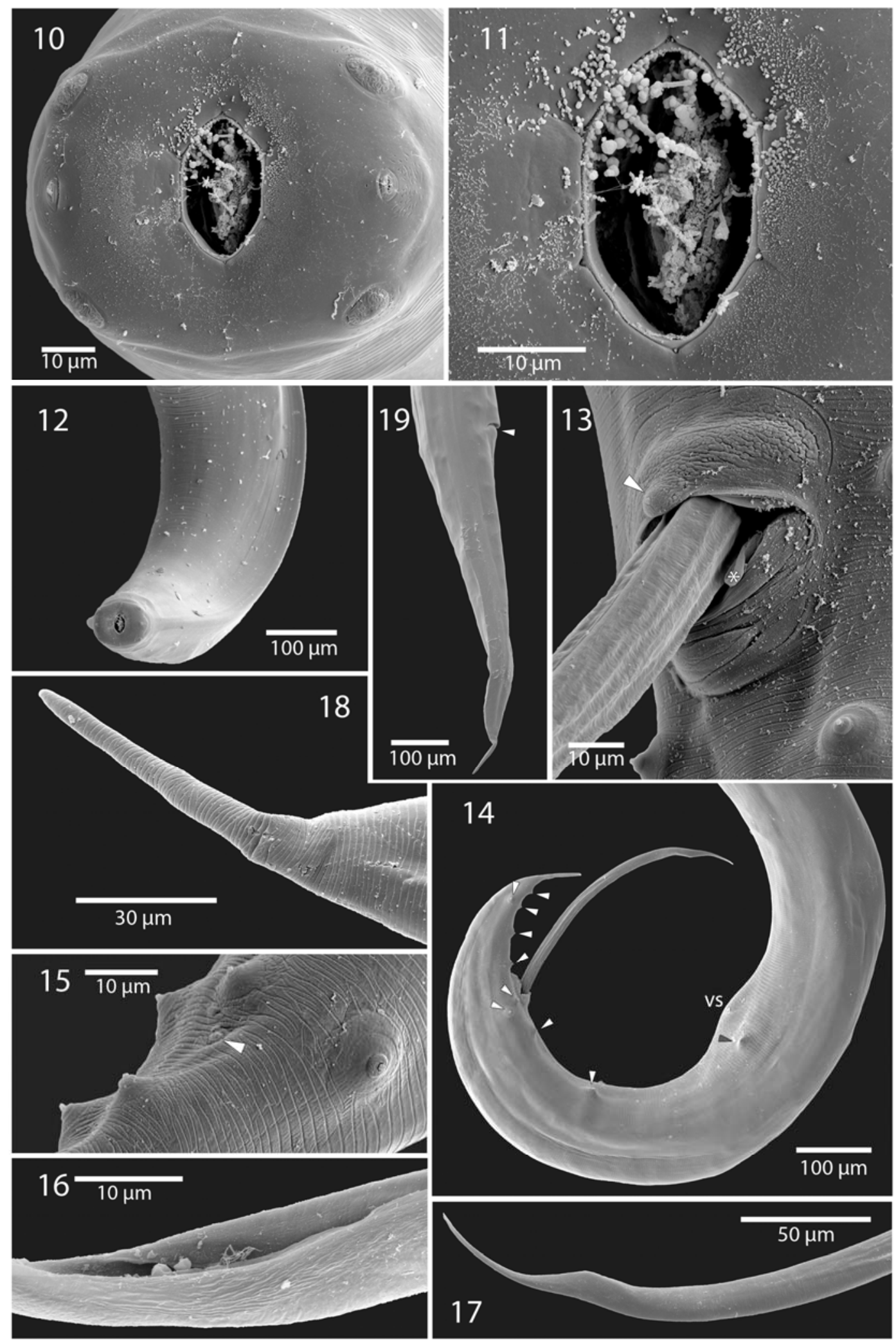

Figs. 10 - 18. Subulura mackoi n.sp.; SEM micrographs. Fig. 10. Female cephalic end (apical view); Fig. 11. Detail of female hexagonal mouth opening with six small labial lobes; Fig. 12. Female anterior end with lateral alae; Fig. 13. Male cloacal region with protruding spicule and distal part of gubernaculum (asterix) and single papilla at upper cloacal lip (arrowhead); Fig. 14. Male posterior end (lateral view) with precloacal sucker

(vs), protruding spicule, arrowheads indicate ten pairs of caudal papillae; Fig. 15. Lower group of postcloacal caudal papillae with phasmid (arrowhead); Fig. 16. Detail of spicule with smooth channel; Fig. 17. Needle-like extremity of spicule; Fig. 18. Female tail point showing annulation; Fig. 19. Female posterior end with anus (arrowhead) 
or 11 pairs of caudal papillae. These are $S$ acutissima Molin, 1860 (typus generis); S. lutzi Barreto, 1919; S. longispicula Wang, 1980; and S. glaucidii (López-Neyra, 1945). Only one species, S. reclinata (Rudolphi, 1819), a specialized parasite of South American Piciformes (Barreto 1919; Vicente et al. 1995), was reported by Kinsella et al. (2001) in Asio otus (L.) from the USA (Florida).

The main distinguishing features of all species from this group are as follows: males (Table 1) - number and topography of caudal papillae, shape of spiculae, length of spiculae, ratio of spiculae length (in \%), tail length, ratio of tail length and body length (in \%); females (Table 2) body length, shape of vulva, distance of vulva to anterior end of body, ratio of vulva distance to body length (in \%), tail length, ratio of tail length and body length (in \%), and egg dimensions.

Subulura glaucidii and S. mackoi n. sp. are similar in the shape of the distal ends of spiculae. The most important distinguishing characters are the presence of the odd papilla on the upper lip of cloaca in S. mackoi n. sp., which is absent in $S$. glaucidii, the number and distribution of the lower group of postcloacal caudal papillae (Figs. 4, 9), and the other above mentioned features. Ferrer et al. (2004) found and assigned nematodes in O. scops in Spain as Subulura spp., without more detailed morphometric data. These nematodes are probably different from the wellknown $S$. bolivari from Athene noctua reported in Spain by López-Neyra (1922) and Illescas et al. (1993) and may be conspecific with $S$. mackoi n.sp.

Two subulurid species with 10 pairs of caudal papillae and unequal or subequal spiculae have been found in non strigiform birds wintering in sub-Saharan Africa and breeding in the temperate zone of the Palaearctic realm. The first is S. subulata (Rudolphi, 1819) parasitizing Caprimulgus europaeus L. (according to Chabaud, 1957, spiculae length 960 and 1540 , eggs $85 \times 55$, female tail length 78). Subulura mackoi n. sp. has smaller spiculae and eggs; the female tail length is slightly longer. The second, S. sisoworonki Iwanizky, 1940 from Coracias garrulus L., is well-differentiated by the length of its subequal spiculae ( 809 and 747), and by its shorter tail (312) in the male (Iwanitzky, 1940). We emphasize that this species has a median odd papilla on the upper lip of the cloaca, similarly to $S$. mackoi sp. n. However, this character is absent or not described in any other avian subulurids. Undoubtedly, zoogeographical aspects and host specificity are important characters for distinguishing these subulurids taxa.

\section{Zoogeographical analysis}

The systematics of the Subuluridae family has been reviewed by Barreto (1919), López-Neyra (1945), Skryabin and Shikhobalova (1949), Skryabin et al. (1954), Inglis (1958, 1960), and Quentin (1969, 1971), and summarized by Chabaud (2009). The nominotypic genus Subulura Molin, 1860 includes numerous species parasitizing birds and mammals; only one ( $S$. lacertilia) parasitizes Brazilian reptile (Vicente et al., 2000). For the zoogeographical analysis of subulurids in birds we prefer to regard Subulura in the broader sense of the generic diagnosis by Yamaguti (1961) and Skryabin et al (1964). In accordance with Bar-

Table 1. Selected differential features (dimensions in $\mathrm{mm}$ ) of male specimens from the genus Subulura with unequal spiculae, parasitizing Strigiformes (S. reclinata found in Asio otus L. by Kinsella et al. 2001)

\begin{tabular}{|c|c|c|c|c|c|c|}
\hline $\mathrm{F}_{\text {Features }}^{\text {Species }}$ & S. acutissima & S. longispicula & S. mackoi n.sp. & S. glaucidii & S. lutzi & S. reclinata \\
\hline Body length & $9.66-10.50$ & $12.80-13.60$ & $10.71-11.69$ & $6.10-8.30$ & 14.0 & 11.0 \\
\hline $\begin{array}{c}\text { Number of caudal } \\
\text { papillae }\end{array}$ & 10 & 10 & $10+1$ & 11 & 11 & 11 \\
\hline $\begin{array}{l}\text { Length of spicula } \\
\text { (1) }\end{array}$ & $1.06-1.26$ & $2.40-3.00$ & $0.539-0.621$ & $0.425-0.490$ & 0.794 & 1.105 \\
\hline $\begin{array}{l}\text { Length of spicula } \\
\text { (2) }\end{array}$ & $1.60-1.81$ & $2.88-3.36$ & $0.807-0.855$ & $0.720-0.860$ & 1.270 & 1.516 \\
\hline $\begin{array}{l}\text { Ratio of spiculae } \\
\text { length (in \%) }\end{array}$ & $66-70$ & $83-89$ & $67-76$ & $56-59$ & 62 & 73 \\
\hline Tail length & $0.26-0.31$ & $0.158-0.160$ & $0.259-0.264$ & $0.150-0.220$ & 0.169 & 0.210 \\
\hline $\begin{array}{l}\text { Ratio tail body } \\
\text { length (in \%) }\end{array}$ & $2.69-2.95$ & $1.18-1.23$ & $2.22-2.45$ & $2.46-2.65$ & 1.21 & 1.90 \\
\hline Hosts & $\begin{array}{c}\text { Glaucidium } \\
\text { brasilianum } \\
\text { (Gmelin) }\end{array}$ & $\begin{array}{l}\text { Ninox scutulata } \\
\text { (Raffles) }\end{array}$ & $\begin{array}{l}\text { Otus scops } \\
\text { (Linnaeus) }\end{array}$ & $\begin{array}{l}\text { Glaucidium } \\
\text { passerinum } \\
\text { (Linnaeus) }\end{array}$ & Strix sp. & $\begin{array}{l}\text { Crotophaga ani } \\
\text { Linnaeus }\end{array}$ \\
\hline Distribution & Brasil & China & $\begin{array}{l}\text { Czech Republic } \\
\text { (Europe) }\end{array}$ & $\begin{array}{c}\text { Spain } \\
\text { (Europe) }\end{array}$ & Brasil & Brasil \\
\hline Reference & $\begin{array}{l}\text { Freitas et al. } \\
\quad(1970)\end{array}$ & Wang (1980) & Our data & $\begin{array}{c}\text { López-Neyra } \\
(1945)\end{array}$ & $\begin{array}{c}\text { Barreto } \\
(1919)\end{array}$ & Barreto (1919) \\
\hline
\end{tabular}


Table 2. Selected differential features (dimension in $\mathrm{mm}$ ) of female species of the genus Subulura, parasitizing Strigiformes (Reference are in Table 1)

\begin{tabular}{|c|c|c|c|c|c|c|}
\hline Features & S. acutissima & S. longispicula & S. mackoi n.sp. & S. glaucidii & S. lutzi & S. reclinata \\
\hline Body length & $7.69-12.15$ & $17.60-18.80$ & $11.90-16.90$ & $10.0-12.3$ & $11.0-22.5$ & $14.30-20.50$ \\
\hline $\begin{array}{c}\text { Distance } \\
\text { vulva-anterior } \\
\text { end }\end{array}$ & $3.23-5.86$ & $\begin{array}{l}\text { Slightly behind } \\
\text { middle of body }\end{array}$ & $5.50-6.43$ & 5.50 & $\begin{array}{l}\text { First third of } \\
\text { body length }\end{array}$ & $\begin{array}{l}\text { Slightly behind } \\
\text { middle of body }\end{array}$ \\
\hline $\begin{array}{l}\text { Ratio vulva/ } \\
\text { body length } \\
\text { (in \%) }\end{array}$ & $42-48$ & - & $38-46$ & 47 & $33-35$ & - \\
\hline Eggs & $0.048 \times 0.040$ & $\begin{array}{c}0.070-0.080 \mathrm{x} \\
0.052-0.056\end{array}$ & $\begin{array}{c}0.046-0.052 \mathrm{x} \\
0.039-0.048\end{array}$ & $\begin{array}{c}0.055-0.060 \mathrm{x} \\
0.040-0.050\end{array}$ & $0.083 \times 0.050$ & $0.076 \times 0.050$ \\
\hline Tail length & $0.830-1.110$ & $0.880-1.080$ & $0.832-0.870$ & $0.400-0.450$ & 0.443 & 1.285 \\
\hline $\begin{array}{l}\text { Ratio tail/ } \\
\text { body length } \\
\text { (in \%) }\end{array}$ & $9.14-10.79$ & $5.00-5.74$ & $5.14-6.99$ & $3.60-4.00$ & $1.96-4.01$ & $6.63-8.98$ \\
\hline
\end{tabular}

reto (1919), Baylis (1936), Yamaguti (1961), Skryabin et al. (1964), Vincente et al. (1995) and others, we accept the genus Allodapa Diesing, 1861 as a synonym of the genus Subulura (see Skryabin et al., 1964). Campana-Rouget (1956) ranked the genus Travassodolapa López-Neyra, 1945 as a synonym of Subulura. The presence of unequal spicules was found in type species S. acutissima Molin, 1860 by Freitas et al. (1970), which supported this synonymy. In addition, Sonin and Baruš (1996) assigned Alaplectana Azim, 1931 and Sood (2006) assigned Inglisubulura Devamma, 1975 as synonyms of Subulura. Primates and occasionally rodents are obligatory hosts of Primasubulura Inglis, 1958. Three species parasitizing birds which Sood (2006) retained in this genus ( $P$. alata Devamma, 1975; $P$. pavonis Devamma, 1975; and $P$. singhi Balamani et Devamma, 1985) evidently belong to Subulura. We agree with Chabaud (2009) that Paraheterakis Nama et Jain, 1974 seems to be a synonym of Subulura. Also Gallioxynema Shamim et Deshmukh, 1980 parasitizing Gallus gallus f. domestica from India, and mentioned by Gibbons (2010), is probably congeneric and a synonym of Subulura.

In the present zoogeographical analysis, we evaluated all valid nominal taxa in species level of the genus Subulura parasitizing birds with remarks on its synonymy and specialization in avian orders.

\section{Palaearctic Realm}

Galliformes - S. amherstii (Azim, 1931); S. brumpti (LópezNeyra, 1922); S. curvata (Linstow, 1883) [syn. Allodapa seurati Barreto, 1917]; S. differens (Sonsino, 1890); S. gracilis (Linstow, 1899); S. gallopavonis López-Neyra, 1945; S. skrjabini (Semenov, 1926) [syn. S. coturnicis Yamaguti, 1941, S. coturnicis López-Neyra, 1945, S. baylisi López-Neyra, 1946]; S. tetraogalli Spaul, 1929 [syn. S. kabulanus Akhtar, 1937]. Strigiformes - S. bolivari; $S$. glaucidii; S. mackoi n. sp.; S. noctuae. Caprimulgiformes -
S. leprincei (Gendre, 1909); S. subulata. Coraciiformes $-S$. sisoworonki. Gruiformes - S. halli Barreto, 1917; S. rima (Linstow, 1906). Charadriiformes - S. skrjabinensis Borgarenko, 1960. Passeriformes - S. brumpti.

Note: Ortlepp (1938), Inglis (1964) and Ogden (1966) considered S. suctoria, $S$. differens and S. brumpti as conspecific. Barreto (1919), Cuckler and Alicata (1944), Skryabin and Shikhobalova (1949) and Hartwich (1975) pointed to significant differences in their zoogeography and hosts (S. suctoria - Caprimulgiformes, Brazil; S. differens and $S$. brumpti - Galliformes, Old World). Subulura brumpti was described from domestic fowl from Spain (Gallus gallus f. domestica) by López-Neyra (1922). Subulura suctoria has not been found in birds of the Old World. Sonin and Baruš (1996) declared that domestic fowl was typical host for $S$. brumpti; however, the parasite was referred from other domestic birds (Meleagris, Numida, Guttera) and very rarely free-living gallinaceous birds. As a result of domestication and the breeding of fowl, the geographic distribution of $S$. brumpti is cosmopolitan. Subulura brumpti was found in Passeriformes (Sturnus vulgaris L.) in the temperate zone in Poland only and reported under the name

S. suctoria (Gundlach, 1965; Okulewicz, 1997). Meredov et al. (1970) reported $S$. suctoria in Athene noctua from Turkmenistan. For the above mentioned reasons we are convinced that this species was misidentified and is probably a different species with equal spicules ( $S$. noctuae or $S$. bolivari) parasitizing Strigiformes in the Palaearctic Region. The species S. coturnicus (Standel, 1874) from Coturnix coturnix (L.) in Ukraine is considered by Sonin and Baruš (1996) as "species inquirenda". Subulura differens was described by Sonsino (1890) from domestic fowl (Gallus gallus f. domestica) in Italy, and is widespread, according to Sonin and Baruš (1996), in domestic fowl and free-living gallinaceous birds (Alectoris, Perdix, Coturnix, Francolinus, Numida) in the southern (subtropical) belt of 
the Palaearctic realm, and in the whole the Afrotropical and Neotropic realms.

\section{Afrotropical Realm}

Galliformes - S. acuticauda (Linstow, 1901); S. brumpti; S. dentigera Ortlepp, 1937; S. differens; S. poculum (Linstow, 1909). Strigiformes $-S$. similis (?). Caprimulgiformes $-S$. subulata ; S. leprincei. Cuculiformes $-S$. similis (?). Coraciiformes - S. recurvata (Linstow, 1901); S. similis. Gruiformes $-S$. otidis Ortlepp, 1938; Coliiformes - S. armata Vuylsteke, 1957. Pelecaniformes - S. plotina Baylis, 1919.

Note: Railliet and Henry (1914) suggested that reports of S. similis by Gendre (1909) from the hosts Coracias abyssinicus Hermann, Eurystomus afer Gray, Centropus monachus Rüppell, C. superciliosus Hemprich et Ehrenberg, and Ptilopsis leucotis might be confused. Barreto (1919) considered that Gendre (1909) was dealing with several species from this wide variety of hosts and suggested that the samples from $E$. afer might be $S$. recurvata described by Linstow (1901) from the same host in Africa (Lake Nyassa). Skryabin (1916) identified S. suctoria (Molin, 1860) from C. superciliosus. Barreto (1919) considered that these nematodes were conspecific with $S$. similis identified by Gendre (1909) from the same host and region (tropical Africa). We prefer to preserve the name S. similis for a taxon from Coraciiformes hosts from Africa. However, redescription of the taxon from the typical host $(C$. abyssinicus) is needed. Junker and Boomker (2007) found subulurids (S. suctoria and S. dentigera) in Guinea fowl Numida meleagris (L.) and Guttera edouardi Hartlaub and provided an overview of their occurrence in African gallinaceous birds which shows that $S$. dentigera is a specialized parasite in this region. In our opinion, the determination of S. suctoria is wrong (see note above - Palaearctic region); it is probably $S$. brumpti. For comparison, redescriptions of $S$. suctoria from Caprimulgus sp. (Brasil) by Barreto (1919), C. cubensis (Lawrence) (Cuba) by Baruš and Lorenzo Hernández (1970), and S. brumpti from $G$. gallus f. dom. (Cuba) by Baruš (1969) could be used. The occurrence of $S$. suctoria in various Madagascan wild birds reported by Inglis (1964) cannot be accepted from the zoogeographical and host perspective.

\section{Indo-Malay Realm}

Galliformes - S. brumpti; S. galloperdicis Baylis et Daubney, 1922; S. minetti Bhalerao, 1941; S. francolinusi Jehan, 1970; S. fotedari Gupta, 1982; S. haitinhensis Phan, 1969; S. indica Rathore et Nama, 1986; S. inglisi (Devamma, 1975); S. multipapillata (Chandler, 1926); S. pavonis (Devamma, 1975); S. perdicularia Dey Sarkar, 1999; S. skrjabini [syn. S. alata (Devamma, 1975), Inglisubulura singhi Devamma, 1975, S. singhi Balamani et Devamma, 1985]; S. taiwanensis Yamaguti, 1935. Strigiformes $-S$. albai; S. chinensis; S. galloperdicis; S. longispicula. Caprimulgiformes - S. tulsidasi Dey Sarkar, 1995; S. galloperdicis. Coraciiformes - S. albai;S. leachii Kirschner, 1938. Cuculiformes - S. rimula (Linstow, 1903); S. sinen- sis Kumar et Gupta, 1976. Falconiformes - S. kanpurensis Gupta, 1980. Passeriformes - S. alii Ilyas, 1982; S. helicospiculata Schmidt et Kuntz, 1971; S. turnicis Maplestone, 1931; S. turdoidae Soota et Dey Sarkar, 1981.

Note: Among the species from this area S. olympioi Barreto, 1919 reported from India (Lucknow) by Gupta and Kazim (1978) in Turdoides striatus (Dumont) (Passeriformes) cannot be included. This species is a specialized parasite of Tinamiformes (Nascimento et al., 1992; Pinto et al., 2006) and its distribution is limited to the Neotropical realm (Barreto, 1919; Vicente et al., 1995). The species S. alata, S. singhi and I. singhi are conspecific to $S$. skrjabini, a specialized parasite of galliform birds in the Old World (genera Alectoris, Perdix, Coturnix, Phasianus, rarely ocuring in Gallus gallus f. domestica); S. skrjabini males are characterized by equal spicules and 11 pairs of caudal papillae. Also S. suctoria reported by Sood (2006) from Caprimulgiformes, Cuculiformes, Galliformes and Coraciiformes was misdetermined in this region. It is probably a "species complex" of a total of 11 taxa previously described mainly from South Asia; they should be subject to revision. Ilyas (1982) gived the names of two new species, Subulura francolini with subequal spicules (840 and 750) and S. schikhobalovi with equal spicules (570 - 1060), with only data about the body length of males and females (figures absent) in the key. Therefore, we consider them as a species inquirenda. Sood (2006) did not mention either name in the checklist of nematode parasites of birds from South Asia. He included Duplicaecum ibisi Majumdar et Chakravarty, 1963 (host Bubulcus ibis L., Ciconiiformes) into Subulura. However, morphologically, it clearly belongs to the order Ascaridida, of the Anisakidae family (because an oesophageal ventriculus, ventricular and intestinal appendices, and a mouth with three lips are present). The findings of $S$. galloperdicis [typical host Galloperdix spadicea (Gmelin), Galliformes] in Tyto alba registered by Sood (2006) and in Caprimulgus sp. by Soota (1981) in India might be considered as host switching. Revision of the species of this genus, which parasitize birds in the Indo-Malayan Region, is badly needed. For example, in one host, Turdoides striatus (Passeriformes) is parasitized by S. alii,

S. olympioi (evidently misdetermined, as it is a specialized parasite of Brasilian Tinamiformes - Vicente et al., 1995; Pinto et al., 2006), S. turdoides and S. turnicis, which is very unusual.

\section{Australasian Realm}

Galliformes - S. brumpti. Cuculiformes - S. clelandi Johnston et Mawson, 1941. Caprimulgiformes $-S$. clelandi.

Note: Ogden (1966) considered S. clelandi described by Johnston and Mawson (1941) from Podargus strigoides Latham, and Scythrops novaehollandiae Latham as synonyms of Allopada (=Subulura) suctoria. The reasons for exclusion of the presence of S. suctoria in birds from these orders in the Australasian Region are given above (Palae- 
arctic and Afrotropical Realms). S. clelandi is evidently a valid taxon in this zoogeographical realm, near to $S$. differens. However, it differs by having a longer body length, shorter spicules, and smaller eggs (Johnston \& Mawson, 1941).

\section{Oceanic Realm}

Galliformes - S. brumpti.

Note: The life cycle of $S$. brumpti was studied for the first time by Alicata (1939) and Cuckler and Alicata (1944) in this zoogeographical realm on Hawaii.

\section{Nearctic Realm}

Galliformes - S. brumpti; S. strongylina (Rudolphi, 1819). Strigiformes - S. forcipata (Rudolphi, 1819); S. reclinata. Passeriformes - S. papillosa (Molin, 1860).

Note: The complex history of the names and synonymy of taxa $S$. forcipata and $S$. strongylina was analyzed by Skryabin et al. (1954). The opinions of Skryabin and Schikhobalova (1949) and Baruš (1970c) that these species recorded in galliform birds of the Old World were misdetermined and that they are the taxon $S$. differens were respected by Sonin and Baruš (1996). Barreto (1919) emphasized the importance of the specialization of these species to their definitive hosts: $S$. forcipata to Cuculiformes and S. strongylina to Tinamiformes in the Neotropical Region (Nasaimento et al., 1992). Samples of nematodes from Caprimulgus sp. denoted by Schneider (1866) as Heterakis forciparia $(=S$. forciparia $)$ were considered as true S. suctoria by Barreto (1919). We consider records of the species $S$. forcipata and $S$. reclinata by Kinsella et al. (2001) in Athene cunicularia and Asio otus (USA, Florida) to indicate a co-accommodation phenomenon or the hostswitching of parasites in places of geographical contact between hosts. The findings of S. strongylina from Colinus virginianus (L.) (Galliformes) in Ohio (USA) by Biester and Schwarte (1968) require revision.

\section{Neotropical Region}

Galliformes - S. brumpti; S. differens. Strigiformes $-S$. acutissima; S. lutzi; S. alfenensis [syn. S. freitaslauroi Pinto, 1970]. Caprimulgiformes - S. suctoria. Cuculiformes - S. carlosi Barreto, 1919; S. forcipata; S. reclinata (Rudolphi, 1819); S. rudolphii Santos, 1970; S. samanamudi Ibáñez, 1969; S. travassosi Barreto, 1919. Trogoniformes - S. bentocruzi Barreto, 1919; S. trogoni Barreto, 1919. Tinamiformes - S. olympioi Barreto, 1919; S. strongylina. Cariamiformes - S. allodapa (Creplin, 1853). Charadriiformes - S. huaynacapaci Freitas, Vincente et Ibáñez, 1968. Passeriformes - S. papilllosa. Anseriformes - Subulura sp.; S. brumpti.

Note: An excellent overview of subulurid nematode fauna parazitizing birds from this region was presented by Barreto (1919) and Vincente et al. (1995), with other species ascertained by Ibañez (1969) and Freitas et al. (1968). Freitas et al. (1970) presented a very important study on the stability of the genus Subulura, with a complete redescription of type species $S$. acutissima from a type host and a type locality (Brasil). This species is specialized to hosts from Strigiformes (Vicente et al., 1995) and has markedly unequal spiculae. The occurrence of subulurids in hosts of Anseriformes is very rare. Only Ribeiro-Machado et al. (2006) recorded Subulura sp. from Cairina moschata (L.), and Baruš and Blažek (1970) experimentaly infected Anas platyrhynchos f. domestica with $S$. brumpti in Cuba.

\section{Discussion}

Barreto (1919), who evaluated 26 taxa parasitizing birds, already noted the importance of host specialization and zoogeographical distribution in identifying morphospecies of the genus Subulura. In our analysis, we considered 68 valid species parasitizing birds currently classified in this genus. Only $S$. brumpti has a cosmopolitan distribution; it is a parasite specialized to domestic fowl (Gallus gallus $\mathrm{f}$. domestica), rarely occurring in other domesticated or wild gallinaceous birds (Sonin \& Baruš, 1996). The cosmopolitan distribution is the result of human activity (poultry farming). For the same reason, $S$. differens is spread over the three zoogeographic regions (Palaearctic, Afrotropical and Neotropical). The natural occurrence of S. skrjabini is in two regions (Palaearctic and Indomalayan); it is a characteristic parasite of wild gallinaceous birds of the genera Coturnix, Perdix, Alectoris, Phasianus, Tetrao, and Francolinus. It has been detected very rarely in domestic fowl (Sonin \& Baruš, 1996). Subulura subulata and S. leprincei occur in the Palaearctic and Afrotropical realms; in the Neotropical and Nearctic realms, the species $S$. forcipata, $S$. reclinata, and $S$. strongylina occur. All other evaluated species and their hosts have zoogeographical distribution in the Old World (45 species), the New World (14 species) and the Australasian Region (2 species). They are distributed mainly in the tropical zone of the Afrotropical, IndoMalayan and Neotropical Regions; smaller number of species extends to the subtropical zone of the Palaeartic and Nearctic Regions, but rarely to the temperate zone. In our opinion, the main factor determining this geographic distribution of subulurids parasitizing birds is the phenomenon of thermophily, which is manifested by the influence and importance of temperature during development of the larval stage in intermediate hosts. This hypothesis is supported by results of studies on the $S$. brumpti development cycle by Alicata (1939), Cuckler and Alicata (1944) in Hawaii, and Abdou and Selim (1957) in Egypt. Baruš (1970a) demonstrated experimentally that in $S$. brumpti (erroneously named $S$. suctoria) in Cuba the development of larvae in intermediate hosts was fully realized only at a temperature of $20^{\circ} \mathrm{C}$ or higher. The development stops at lower temperatures. Although intermediate hosts (various species of Dermaptera, Blattaria, Orthoptera, and Coleoptera) and gallinaceous domestic birds as definitive hosts are present in the temperate zone of the appropriate zoogeographical area, the lower temperature inhibits or completely excludes the life cycle and thus the infection of hosts (Baruš, 1970b). 
Therefore, the temperature is the main zoogeographical factor that determines the presence and distribution of $S$. brumpti and probably most of the other species of the genus Subulura parasitizing birds.

Infection with subulurids in birds nesting in temperate zones of geographical regions (the northern zone in the Palaearctic Region in our case) was observed only in hosts wintering in tropical regions. S. subulata parasitizing $C$. europaeus had its northernmost distribution in the Palaearctic Realm (Czech Republic - Sitko \& Okulewicz, 2010; Austria Rudolphi, 1819); in the southern zone of Palaearctic Region it was reported from Algeria, Spain, Corsica, and Tunisia (López-Neyra, 1945; Chabaud, 1957). Subulura leprincei from $C$. europaeus was reported in the northern zone in Belorussia (Merkusheva \& Bobkova, 1981), and in the southern zone in Georgia (Kurashvili 1957), Armenia (Akhumyan, 1966), Turkmenistan (Meredov, 1976) and Spain (Cordero del Campillo et al., 1977). A single record of S. brumpti from Sturnus vulgaris was reported from Poland (Gundlach, 1965; Okulewicz, 1997). S. sisoworonki was reported from C. garrulus in Azerbaijan (Sadychov, 1970), Turkmenistan (Meredov et al., 1970) and Ukraine (Ivanickyi, 1940). S. skrjabini from Alectoris chukar (Gray), Francolinus francolinus (L.) and Perdix perdix (L.) was found in Armenia (Akhumyan, 1966); S. skrjabinensis from Burhinus oedicnemus (L.) was found in Kazakhstan (Gvozdev \& Kasymzhanova, 1965) and Tajikistan (Borgarenko, 1960, 1990). Data on the presence of $S$. allodapa from Alectoris chukar in Armenia (Akhumyan, 1966) and Azerbaijan (Vaidova, 1964; Kasimov, 1947, 1956; Kasimov \& Feyzullaev, 1965) are wrong, because this species is a specialized parasite of Cariama cristata (L.) (Cariamiformes) in the Neotropical Region in Brasil (Vincente et al., 1995). This is probably a species characteristic to gallinaceus birds in the Palearctic Realm (males possess from 10 to 11papillae and equal or subequal spicules, which corresponds with S. brumpti or S. differens). This phenomenon, the origin of bird parasites and their transmission from wintering (epiareal) to nesting (euareal) territory, was analyzed by Dogel (1962). The abovementioned species of Europaean subulurids of the Palaearctic Realm evidently belong to the group of "southern species" which infect hosts in the wintering grounds. Birds are not infected by these parasites in the nesting grounds, and parasitic fauna of these hosts disappears. Many intestinal helminths live approximately one to three months, so findings of southern species in the nesting areas are rare and limited to a relatively short time after arrival. Another reason for the rare occurrence of subulurids in the Czech Republic is the fact that they parasitize hosts with a small population density and often at the northern boundary of their distribution ( $C$. garrulus, O. scops, B. oedicnemus). Parasitological research in the Czech Republic has not been carried out on some migratory bird species which are infected by subulurids in other zoogeographic regions - for example, Cuculus canorus L. and Coturnix coturnix L.

The zoogeography and host specialization of the genus Subulura, which includes numerous species, manifest interesting and taxonomically significant relationships that can be used to identify morphospecies.

\section{Acknowledgement}

This study was supported by the Department of Botany and Zoology, Faculty of Science, Masaryk University; other thanks are due to the FEI Czech Republic.

\section{References}

Abdou, A., Selim, M. K. (1957): On the life history of Subulura suctoria a caecal nematode of poultry in Egypt. Z. f. Parasitenk., 18: $20-23$

AKHUMYAN, K. S. (1966): Species composition of helminths of game bird and other wild birds of the Armenian SSR. Biologicheskiy Zhurnal Armenii, 19: 97 - 104 (In Russian)

AlicATA, J. E. (1939): Preliminary note on the life history of Subulura brumpti, a comon caecal nematode of poultry in Hawaii. J.Parasitol., 25: $179-180$

BARRETO, DE B. A. L. (1919): Sobre as especies brasileiras da sub-familia Subulurinae Travassos, 1914. Mém. Inst. Oswaldo Cruz, 11: 10 - 70

BARUŠ, V. (1969): Studies on the nematode Subulura suctoria. I. Morphological and morphometrical variability. Folia Parasitol., 16: 303 - 311

BARUŠ, V. (1970a) Studies on the nematode Subulura suctoria II. Development in the intermediate host. Folia Parasitol., 17: 49 - 59

BARUŠ, V. (1970b): Studies on the nematode Subulura suctoria III. Intermediate hosts. Folia Parasitol., 17: 191 - 199 BARUŠ, V. (1970c): Survey of nematodes of the family Subuluridae parasitic wild and domestic birds of Cuba. Helminthologia, 11: $11-21$

BARUŠ, V., BLAŽEK, K. (1970): Studies on the nematode Subulura suctoria III. Development in the definitive host. Folia Parasitol., 17: 141 - 151

BARuš, V., Lorenzo Hernandéz N. (1970): Nemátodos parásitos de aves en Cuba. Parte IV. Poeyana (serie A), 88: $1-15$

BAYLIS, M. A. (1936): Nematoda I. (Ascaroidea and Strongyloidea). The Fauna of British India including Ceylon and Burma. Taylor and Francis, London, 408 pp.

BAYLis, M. A., DAubneY, R. (1922): Report on the parasitic Nematodes in the collection of the Zoological Survey of India. Mem. Indian Mus. Calcutta, 7: 263 - 347

Biester, H. E., SchWARTE, L. H. (1968): Enfermedades de las aves. Instituto del Libro, La Habana (Edición revolucionaria), $1113 \mathrm{pp}$.

BorgarenKO, L. F. (1960): The nematodes of game birds in Tajikistan. Izv. Otd. Selskochoz. biol. Nauk AN Taj. SSR, 1: 119 - 133 (In Russian)

Borgarenko, L. F. (1990): Helminths of birds of Tadjikistan. Book 3. Nematodes. Publ. House Donisch, Dushanbe, Tajikistan, 260 pp. (In Russian)

CAmpanA-Rouget, Y. (1956): Sur un nouveaux Subuluridae de 1' écureuil, Xerus rutilus (Cretzchm, 1956). Ann. Parasitol. Hum. Comp., 31: 288-301 
Chabaud, A. G. (1957): Nématodes parasites d'oiseaux en Tunisie. Arch. Inst. Pasteur, Tunisia, 34: 155 - 165

Chabaud, A. G. (2009): 11. Ascaridida, Subuluroidea In Anderson R. C., Chabaud A. G., Willmott S. (Eds.), Key to the Nematode Parasites of Vertebrates (Archival Volume). CAB International 2009: 324 - 333

Cordero DEl CAMPILlo, M. (1977): Índice - Catalogo de Zooparasitos Ibéricos. III. Cestodos, IV. Nematodos y Anejos. León (Espańa), 207 pp.

CRAM, E. (1927): Bird parasites of the nematodes suborders Strongylata, Ascaridata and Spirurata. U. S. Natl. Mus. Bull., 140: 1 - 465

Cuckler, A. C., AlicATA, J. E. (1944): The life history of Subulura brumpti, a caecal nematode of poultry in Hawaii. Trans. Am. Microsc. Soc., 63: 345 - 357

Del Hoyo, J., Elliot, A., SARgatal, J. (1999): Handbook of the Birds of the World. Vol. 5. Barn-owls to Hummingbirds. Lynx Edicions, Barcelona, 760 pp.

Dogel, V. A. (1962): General parasitology. Publ. House Leningrad, 464 pp. (In Russian)

Ferrer, D., Molina, R., Castella, J., Kinsella, J. M. (2004): Parasitic helminths in the digestive tract of six species of owls (Strigiformes) in Spain. Vet. J., 167: 181 185. DOI: 10.1016/S1090-0233(03)00103-5

Freitas, J. F. T., VINCETE, J. J., IBÁŇEZ, N. H. (1968): Fauna helmintológica do Peru: Subulura huaynacapaci sp. n. (Nematoda, Subuluroidea). Atas. Soc. Biol. Rio de J., 12: 85 - 86

Freitas, J. F. T., Vincente, J. J., SANTOS, E. (1970): Sobre Subulura acutissima Molin, 1860 (Nematoda, Subuluroidea). Atas Soc. Biol. Rio de J., 13: 49 - 52

GENDRE, E. (1909): Notes d'helminthologie africaine (premiére Note). Actes Soc. Linn. Bordeaux, 63: 29 - 33

GibBOns, L. M. (2010): Keys to the nematode parasites of vertebrates. Supplementary Volume. CAB International, Wallingford (UK), $416 \mathrm{pp}$.

GundLACH, J. L. (1965): The helminth parasites of the starling (Sturnus vulgaris L.) of the Lublin Palatine. Acta Paras. Polon., 13: $215-225$

GuPTA, S. P., KAZIM, M. (1978): Nematode parasites of birds. Indian J. Helmintol., 30:57 - 67

Gvozdev, E. V., Kasymzhanova, B. A. (1965): On the fauna of nematodes of wild birds in southern Kazakhstan. Proceedings of the Conference of VOG 1965, 1: $54-58$ (In Russian)

Hartwich, G. (1975): Die Tierwelt Deutschlands. 62. Teil. I. Rhabditida und Ascaridida. VEB Gustav Fischer Verlag Jena, $256 \mathrm{pp}$.

Hudec, K., ŠŤAstnÝ, K. (eds.) (2005): Fauna of the Czech Republic. Aves 2. Publ. House Academia, Prague, 1204 pp. (In Czech)

IBÁÑEZ, N. H. (1969): Subulura samanamudi sp.n. nuevo nematodo en la helmintología peruana (Nematoda, Subuluroidea). Bol. Chil. Parasitol., 24: 137 - 138

Illescas, M. P., Rodríguez, M., Aranda, F. (1993): Parasitation of falconiform, strigiform and passeriform (Corvidae) birds by helminths in Spain. Res. Rev. Parasitol., 53: $129-135$

ILYAS, R. (1982): A key to the sixty two species of
Subulura Molin, 1860 and a new species of Subulura from Turdoides somervillei. Rivista di Parassitol., 43: 33 - 41

INGLIS, W. G. (1958): The comparative anatomy of the subulurid head (Nematoda): with a consideration of the systematic importance. Proc. Zool. Soc. London, 130: 577 - 604

INGLIS, W. G. (1960): Further observations on the comaparative anatomy of the head in the nematode family Subuluridae: with the description of a new species. Proc. Zool. Soc. London, 135: 125 - 136

INGLIS, W. G. (1964): Functional deformation in the head of the genus Allodapa (Nematoda). J. Helminthol., 38: 31 - 40 IVANICKYI, S. V. (1940): Helminth fauna of vertebrates of Ukraine (fauna of tapeworms, nematodes and acanthocephala). Sb. Trud. Charkovskogo Vet. Inst., 14: 129 - 155 (In Russian)

Johnston, T. H., Mawson P. M. (1941): Some nematode parasites of Australian birds. Proc. Linn. Soc. N.S.W., 65: $250-256$

JUNKER, K., BOOMKER, J. (2007): Helminths of guinea fowls in Limpopo Province, South Africa. Onderstepoort J. Vet. Res., 74: $265-280$

KASIMOV, G. B. (1947): Francolinus orientalis caucasicus But. as a new host for two nematode species. Dokl. AN Azerb. SSR, 3(10): 467 - 470 (In Russian)

KASIMOV, G. B. (1956): Helminth fauna of game birds of the order Galliformes. Akad. Nauk SSSR, Moscow, 554 pp. (In Russian)

Kasimov, G. B., Feyzullaev, M. A. (1965): Helminth fauna of birds (Galliformes, Columbiformes, Otidiformes, Ciconiiformes) Kura-Araksinsk region of Azerbaijan. Trudy inst. zool. AN Azerb. SSR, 24: 85 - 98 [in Russian] Kinsella, J. M., ForTer, G. W., Forrester, D. J. (2001): Parasitic helminths of five species of owls from Florida, USA. Comp. Parasitol., 68: 130 - 134

KURASHVILI, B. E. (1957): Helminths of game birds of Georgia. Izd. Akad. Nauk SSSR, Moskva, 434 pp. (In Russian)

Linstow, O. (1901): Helminthen von den Ufern des Nyassa-Sees; ein Beitrag zur Helminthen Fauna von Süd Afrika. Jenaische Zeitschr. Naturwiss., 35: 409 - 428

LÓPEZ-NEYRA, C. R. (1922): Notas helmintológicas (4 série) con dos species nuevas del género Allodapa. Boll. Soc. Esp. Hist. Nat., 22: $402-418$

LÓPEZ-NEYRA, C. R. (1945): Estudios y revisión de la familia Subuluridae, con descripción de especies nuevas. Rev. Ibér. Parasit., 5: 271-329

MAŠOVÁ, Š. (2012): Structure of the cephalic end and eggs of female Cithariniella khalili Petter, Vassiliadès et Troncy, 1972. Nematoda: Pharyngodonidae), a parasite of African fishes. Helmithologia, 49: 115 - 118. DOI: 10.2478/s11687-012-0002-5

MEREDOV, M. (1976): Nematode and acanthocephalan fauna of game birds of Turkmenistan. Izv. Akad. Nauk Turkm. SSR, (Biol. 1), 12: 70-74 (In Russian)

Meredov, M., LARChenKo, T. T., Belskaya,G. S. (1970): Nematodes from cave birds of Turkmenistan. Izv. Akad. Nauk Turkm. SSR (Biol. 1), 6: 63 - 69 (In Russian) Merkusheva, I. V., Bobkova, A. F. (1981): Helminth 
fauna of domestic and wild animals of Belarus. Catalogue. Publ. House Nauka i technika, Minsk, 119 pp. (In Russian) Molin, R. (1860): Trenta specie di nematodoidi. Sitzungs Math.-Naturw. Cl. Kaiserl. Acad. Wissensch. Wien, 440: $331-358$

Nasaimento, A. A., Tebaldi, J. H., Antunes, R. C., Arantos, I. G. (1992): Especies de Subulura Molin, 1860 (Nematoda, Subuluroidea) parasitos de Tinamidae nos estatos de Sao Paulo e Mato Grosso do Sul. Revista Brasil. Paras. Vet., 1: $93-95$

OGden, C. G. (1966): Some parasitic nematodes from Australian birds. Ann. Mag. Nat. Hist., ser. 13, 9: 505 - 518 OKulewicz, A. (1997): Catalogus Faunae Parasiticae Poloniae. IV. Parasiti Avium. 2 B. Nematoda. Warszava, 147 pp. Olson, D. M., Dinerstein, E., Wikramanayake, E. D., Burgess, N. D., Powell, G. V. N., Underwood, E. C., D’Amico, J. A., ItouA, I., Strand, H. E., Morrison, J. C., Loucks C. J., AllnutT, T. F., Ricketts, T. H., KuRA, Y., LamoreuX, J. F., Wettengel, W. W., Hedao, P., KASSEM, K. (2004): Terrestrial ecoregions of the world: A new map of life on Earth. BioScience, 51: 933 - 938

Ortlepp, R. J. (1938): South African helminths. Part V. Some avian and mammalian helminths. Onderstepoort $J$. Vet. Res., 11: $63-104$

PINTO, R. M. (1968): Sôbre un nôvo nematodeo parasito de caboré do campo (Nematoda, Subuluroidea). Atas. Soc. Biol. Rio de J., 11: 189 - 190

Pinto, R. M., Knoff, M., Gomes, C. T., Noronha, D. (2006): Helminths of the Spotted Nothura, Nothura maculosa (Temminck, 1815) (Aves, Tinamidae) in South America. Parasitol. latinoam., 61: 152 - 159

Quentin, J. C. (1969): Cycle biologique de Subulura williaminglisi Quentin, 1965. Ontogénèse des structures céphaliques. Valeur phylogénetique de ce caractère dans la classification des Nématodes Subuluridae. Ann. Paras. Hum. Comp., 44: $451-484$

Quentin, J. C. (1971): Sur les modalités d'évolution chez quelquez lignées d'helminthes de rongeurs Muroidea. Cah. ORSTOM, ser. Ent. Med.et Parasitol., 9: 103 - 176

RAIlliet, A., HENRY, A. (1914): Essai de classification des Heterakidae. Extr. IX e Congr. Int. Zool., Monaco, 674 $-682$

Ribeiro Machado, A. C., Mareira Lima, O., De Barros ARAÚJO, J. L. (2006): Helminthos parasitos em aves anseriformes que ocorrem em Goiás. Rev. patol. trop., 35: $185-198$

RUDOLPHI, C. A. (1819): Entozoorum synopsis, cui accedunt mantissa duplex et index locupletissimus. Sumtibus Augusti Rücker, Berolini, 811 pp.

SADYCHOV, R. D. (1970): Helminth fauna of birds of Nakhichevan, Azerbaijan. Issledovanija po gelmitologii v Azerbaijane. Baku, Elm, 192 - 165 (In Russian)

SCHNEIDER, A. (1866): Monographie der Nematoden. Berlin, $357 \mathrm{pp}$.

SEURAT, L. G. (1914): Sur quelques Heterakis d'oiseaux. Bull. Soc. Hist. Nat. Afr. N., 6: $195-202$
SitKo, J., OKulewicz, A. (2010): Checklist of the Nematodes in Birds in the Czech Republic and Slovak Republic. Comenius Museum, Přerov, 104 pp.

SKRYABIN, K. I. (1916): Parasitic Trematodes and Nematodes collected by the expedition of prof. V. Dogiel and I. Sokolov in British East Africa. Science Research Expedition to British East Africa and Uganda, V. Dogiel and I. Sokolov in 1914, vol. 4: 1 - 157 (1 - 98 in Rusian, 99 - 157 in English) Skryabin, K. I., Shikhobalova, N. P. (1949): Parasitic nematodes and the diseases caused by them. Oxyurata. Vol. 1. Moscow, Izd. Academii Medicinskich nauk SSSR, 613 pp. (In Russian)

Skryabin, K. I., Shikhobalova, N. P., Sobolev, A. A., Paramonov, A. A., Sudarikov,V. E. (1954): Key to parasitic nematodes. Vol. IV. Camallanata, Rhabditata, Tylenchata, Trichocephalata, Dioctophymata and hosts distribution of nematodes. Izd. AN SSSR Moscow, 927 pp. (In Russian)

Skryabin, K. I., ShiKhobalova, N. P., LAgOdovSKAYA, E. A. (1964): Principles of nematology. XIII. Oxyurata of animals and man. Part 3. Moscow, Nauka, 468 pp. (In Russian) SONIN, M. D., BARUŠ, V. (1996): Nematodes of wild galliform birds of the Palaearctic Region. Moscow, 177 pp. (In Russian)

Sonsino, P. (1890): Un nuovo Heterakis del Gallus domesticus, Heterakis differens mihi. Atti Soc. Tosc. Sc. Nat., Pisa, Proc. Verb., 6: $224-237$

SootA, T. D. (1981): On some nematodes from the unnamed collection of the Zoological Survey of India, along with the description of a new species. Rec. Zool. Surv. India, 79: $55-71$

SoOTA, T. D., Dey SARKar, S. R. (1981): On some nematodes parasitic in vertebrate hosts from Bihar, India. Rec. Zool. Surv. India, 78: $121-127$

SooD, M. L. (2006): Nematodes parasites of birds (including poultry) from South Asia. International Book Distributing Co., India, Lucknow, 824 pp.

VAIDOVA, S. M. (1964): Fauna and distribution of bird nematodes from Lenkoran region and Mugan steppe (Azerbaijan). Izv. AN Azerb. SSR, ser. biol,. 6: 23 - 32 (In Russian)

Vicente, J. J., Rodrígues, H. O., Gomes, D. C., Pinto, R. M. (1995): Nematóides do Brasil. Parte IV. Nematóides de Aves. Revta Bras. Zool., 12 (Supl. 1): 1 - 273

Vicente, J. J., Sluys, M. V., Fontes, A. F., Kiefer, M. C. (2000): Subulura lacertilia sp.n. (Nematoda, Subuluroidae) parasitizing the Brasilian lizard Tropidurus nanuzae Rodrigues (Lacertilia, Tropiduridae). Revta Bras. Zool., 17(Supl. 4): 1065 - 1068

WANG, P. (1980): Studies on some new nematodes of the suborder Oxyurata from Fujian, China. Acta Zootax. Sinica 5: 242 - 252 (In Chinese)

Yamaguti, S. (1961): Systema Helminthum III. The Nematodes of Vertebrates. Part I, II. Interscience Publ. New York. 1261 pp.

ACCEPTED DECEMBER 5, 2012 